\title{
Optimised captive husbandry conditions for the Western Australian 'Marri Millipede' Antichiropus variabilis (Diplopoda: Polydesmida: Paradoxosomatidae), with notes on natural history and tissue preservation techniques
}

\author{
Janine M. Wojcieszek', Mark S. Harvey ${ }^{2,1}$ and Michael G. Rix ${ }^{2}$ \\ 'Centre for Evolutionary Biology, School of Animal Biology M092, University of Western Australia, 35 \\ Stirling Highway, Crawley, Perth, Western Australia 6009, Australia. Email: wojcij01@student.uwa.edu.au \\ ${ }^{2}$ Department of Terrestrial Zoology, Western Australian Museum, Locked Bag 49, Welshpool D.C., \\ Perth, Western Australia 6986, Australia.
}

\begin{abstract}
The millipede genus Antichiropus Attems, 1911, is extremely diverse and the majority of species are endemic to south-western Western Australia. Very little is known about the general biology of species of Antichiropus; however, these millipedes are becoming useful models for studies of speciation and sexual selection, and remain central to SRE-based conservation planning for government and industry in the expanding resources sector of Western Australia. This paper details optimised captive husbandry conditions and observations made regarding the natural history of one species - Antichiropus variabilis - following three years of field collecting and laboratory-based behavioural and molecular research.
\end{abstract}

\section{INTRODUCTION}

The genus Antichiropus is an extremely diverse group of largely short-range endemic (SRE) millipedes (Harvey 2002), occurring in south-western Western Australia and western South Australia (Harvey and Mesibov 2007). There are currently nine described species within the genus Antichiropus (Attems 1911; Jeekel 1982; Shear 1992). However, preliminary investigation of male gonopod morphology for specimens currently lodged in museum collections suggest there are at least an additional 120 species yet to be described, and a taxonomic revision of Antichiropus is currently underway (Harvey, Edward and Wojcieszek, unpublished data). Antichiropus millipedes are increasingly becoming the subject of research into behavioural ecology, sexual selection, biogeography and speciation (Harvey 2002; Moir et al. 2009; Wojcieszek and Simmons 2009; Wojcieszek and Simmons, unpublished manuscript), and remain central to SRE-based conservation planning for government and industry in the expanding resources sector of Western Australia (Environmental Protection Agency 2009). Antichiropus variabilis Attems, 1911 (Figure 1) - the 'Marri Millipede' - is the most geographically widespread species in the genus, found in Marri (Corymbia calophylla) and Jarrah (Eucalyptus marginata) forests along much of the Darling Escarpment east of Perth (Harvey 2002) (Figure 2). Recent research investigating sexual selection in $A$. variabilis required the development of captive husbandry procedures for laboratory experiments, and these lab-rearing conditions have been slowly improved over successive years. Much has also been learned about the natural history of $A$. variabilis. Given that information on millipede husbandry, natural history and life cycles is generally lacking, the preliminary data presented in this paper should be of use to researchers who need to collect, house and study Antichiropus, and potentially other millipedes, in the future.

\section{METHODS}

Behavioural ecology research was conducted at the University of Western Australia (School of Animal Biology), using A. variabilis specimens collected over three successive years (2007-2009). Millipedes were collected by hand-sifting through leaf litter from various localities across the species range, and large-scale, laboratory-based mating experiments were conducted in 2007 and 2009, using specimens from Serpentine Falls National Park $\left(32^{\circ} 22^{\prime} \mathrm{S}, 116^{\circ} 00^{\prime} \mathrm{E}\right)$ (see Figure 2). During experiments, 

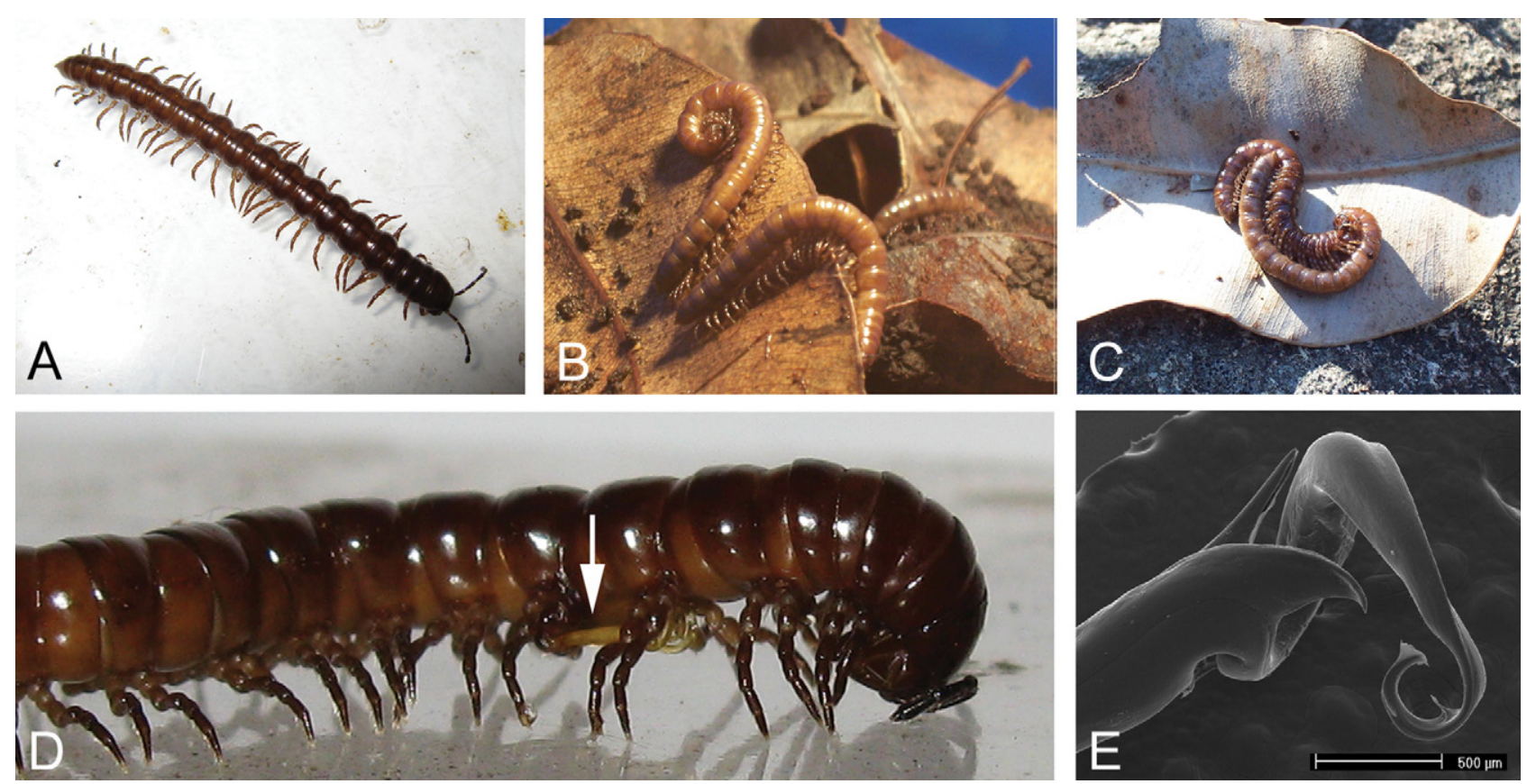

FIGURE 1 Antichiropus variabilis Attems, 1911, the Western Australian 'Marri Millipede': A, adult male walking in captivity; B, millipedes feeding on eucalypt leaves in captivity; C, wild-caught mating pair (male is lower-most); D, anterior segments of adult male, showing location of large (golden) ventral gonopods; E, scanning electron micrograph (SEM) of male left gonopod, showing the distal processes. Note that gonopod morphology is the primary diagnostic feature used for species identification in Antichiropus millipedes. Images by M. Rix and M. Wojcieszek.

adult millipedes were housed in captivity for approximately four months (May to July), during which time the animals were mated, females laid eggs and offspring emerged (detailed behavioural observations are provided elsewhere; Wojcieszek and Simmons, unpublished manuscript). Our results detail the optimised conditions used for captive breeding, and also observations made regarding the natural history of $A$. variabilis.

\section{RESULTS AND DISCUSSION}

\section{FIELD COLLECTING}

Antichiropus variabilis millipedes were generally patchily distributed, and often found in relatively small areas within larger forests. In the Jarrah-Marri eucalypt forests that dominate the Darling Escarpment (Figure 3), specimens were commonly found in thick Marri (Corymbia calophylla) leaf litter and to a lesser extent in Jarrah (Eucalyptus marginata) leaf litter. Most animals were found in the leaf litter layer itself, or underneath the litter, on top of the soil surface. Sometimes specimens were found buried in the soil or lying concealed under fallen logs. Millipedes were rarely found in extremely wet leaf litter, preferring thick, decaying humus that was relatively moist. Individuals were often more common along hills and slopes, possibly because drainage of water was more efficient in these areas. At isolated localities on the Swan Coastal Plain (e.g. Kings Park and Bibra Lake), specimens were often found walking on sand and leaf litter during cool, overcast or rainy conditions.

\section{BEHAVIOURAL OBSERVATIONS}

Millipedes of many species appear to be polygynandrous (Barnett et al. 1993, 1995), that is, males and females mate multiple times in a single breeding season, and this is certainly the case for $A$. variabilis. Adult male A. variabilis millipedes almost always attempt to mate with any females they come into contact with (J. Wojcieszek, pers. obs.). As a result, when females were in the presence of multiple males, females were forced to mate several times in quick succession, causing great stress to the females and potentially also physical damage. Indeed, on the few occasions when this occurred, females usually died one or two days post-mating. In addition, males kept in close proximity to other males also attempted to mate with one another frequently; this also seemed to cause stress and damage to some males. When millipedes become stressed, they release one of a number of chemical compounds; for Antichiropus millipedes (as with most Polydesmidan millipedes; Hopkin and Read 1992: 154), gaseous hydrogen cyanide is released. A build up of this toxic gas in collecting containers may have led to mass fatalities when individuals were, on one occasion, kept overnight in high density without ventilation ( $\mathrm{J}$. Wojcieszek, pers. obs.).

\section{TRANSPORT OF MILLIPEDES FROM FIELD TO LABORATORY}

We recommend that the following precautions be 


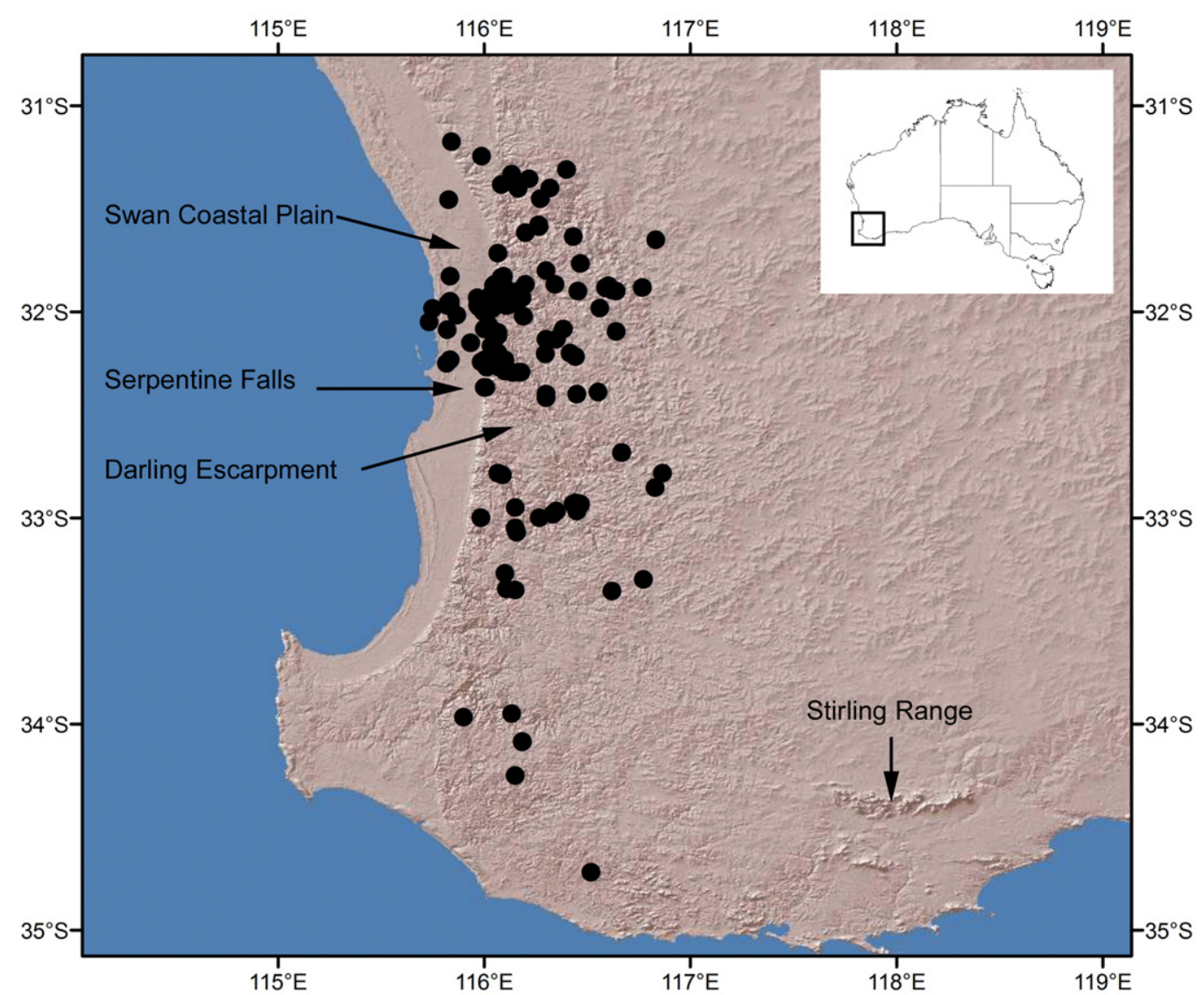

FIGURE 2 Map showing collection records for Antichiropus variabilis as of February 2010. Millipedes are most common on the uplifted Darling Escarpment, and there are some isolated populations on the Swan Coastal Plain.

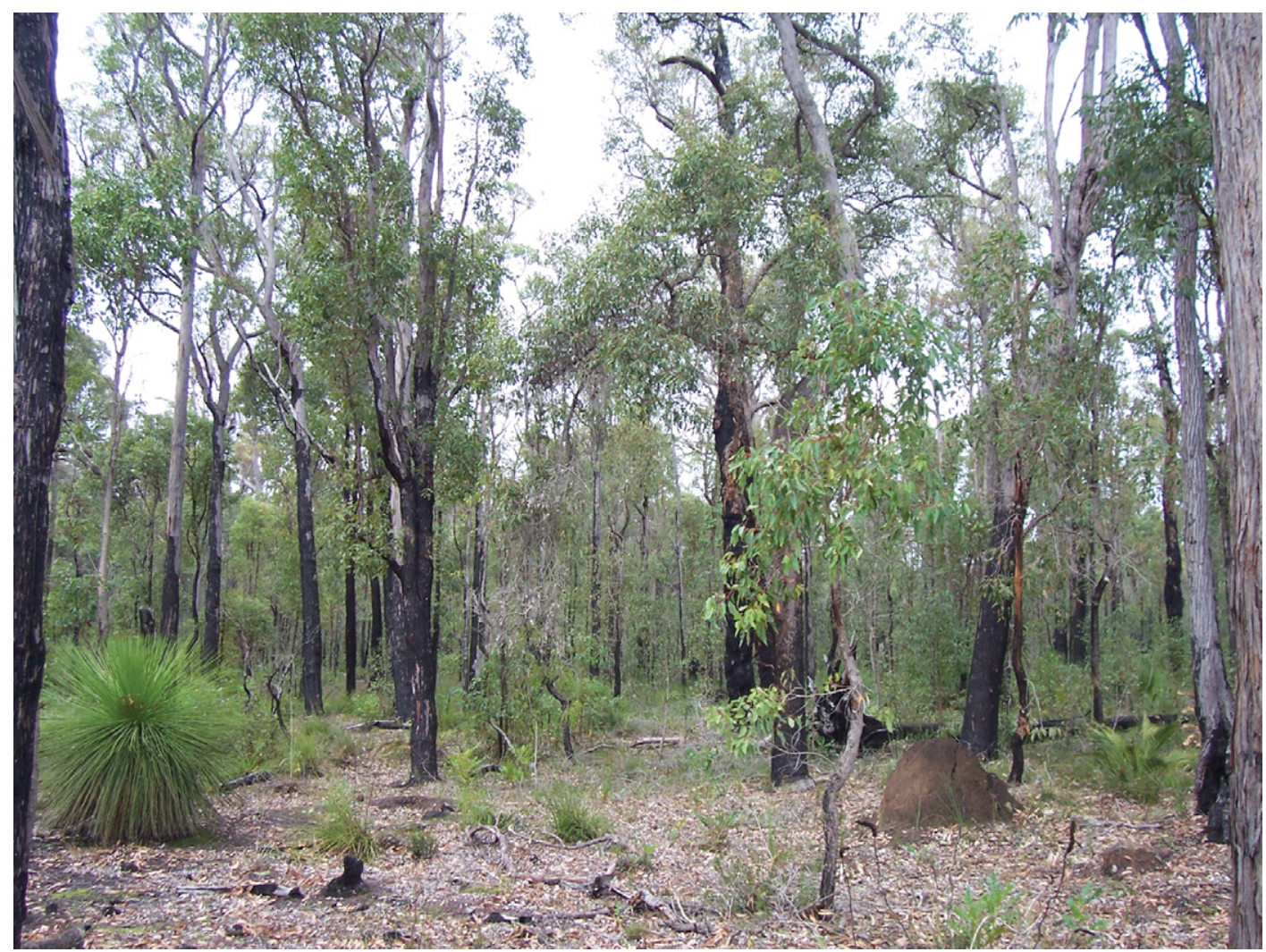

FIGURE 3 Marri and Jarrah forest north of Manjimup in Western Australia. Millipedes prefer forest patches such as these that are relatively open with little understory, and specimens of Antichiropus variabilis were found scattered in the leaf litter. Image by M. Rix. 

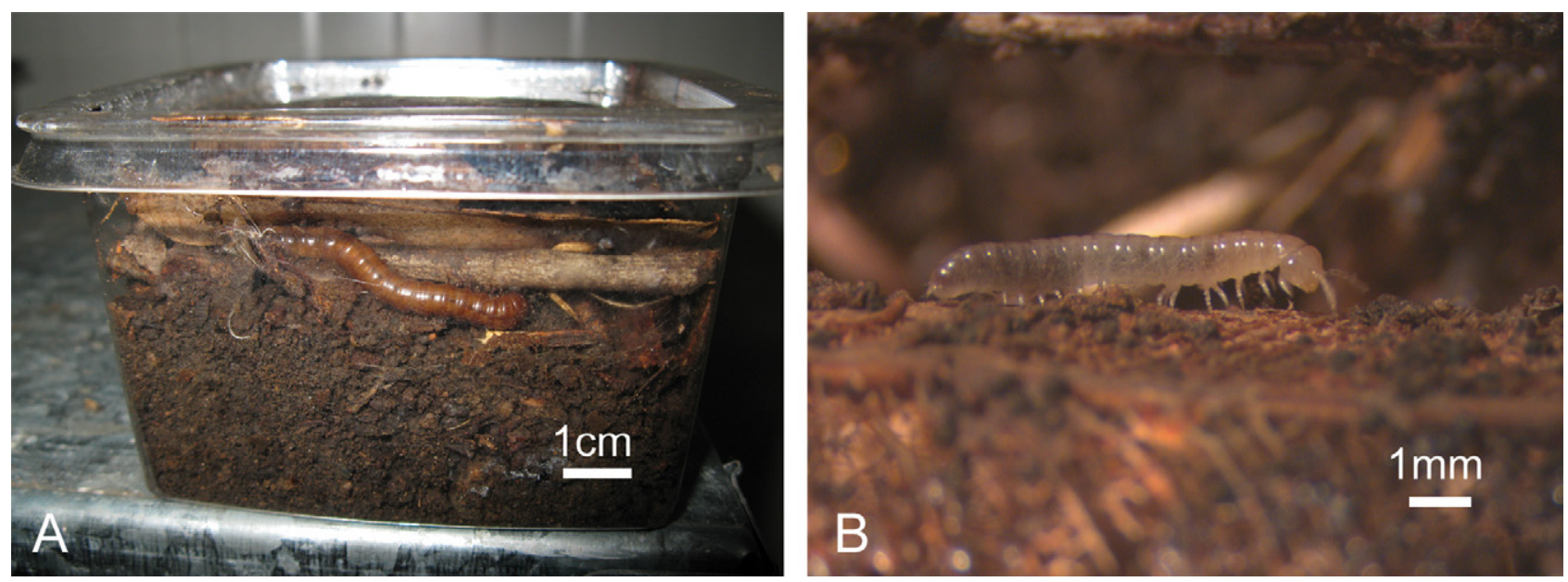

FIGURE 4 Specimens of Antichiropus variabilis in captivity: A, example of the plastic containers used to house individual millipedes; an individual female can be seen. Note that the container is at least half-filled with soil, and the soil is covered with decaying leaf litter; B, juvenile Antichiropus variabilis approximately 20 weeks old. Images by M. Wojcieszek and J. Wojcieszek, respectively.

taken when collecting live animals in the field: (1) males and females should be separated while collection is occurring; (2) the numbers of animals kept together in single containers should be kept to a minimum; and (3) each animal should ideally be placed into its own, well-ventilated, individual container as soon as possible, following collection.

\section{LABORATORY HUSBANDRY}

Millipedes feature in the pet trade, and the giant round millipedes of the orders Spirostreptida and Spirobolida seem to be the most popular to keep as pets. These giant round millipedes can generally survive in terrariums and will eat various fruit and vegetable items, including apple, lettuce, peas and tomato (see Walls 1999 for a general guide to housing and feeding millipedes as pets). We did not attempt to house millipedes in large tanks, as our experiments necessitated isolation of individuals. We found that transparent plastic containers $(8 \times 8 \times$ $8 \mathrm{~cm}=512 \mathrm{~cm}^{3}$ ), with small punctured air holes, were suitable for housing individual A. variabilis (Figure 4). Millipedes thrived when containers were at least halffilled with soil from the collection site, and covered with decaying leaf litter (predominantly Marri litter for $A$. variabilis). Although we did not try multiple food items, we found that millipedes naturally fed on decomposing Marri leaves, nuts, bark and twigs. The millipedes survived best when most of the litter was moist, highly degraded and almost black in colour. Large bags of moist, decomposing leaf litter were taken from the site of collection to supply as food throughout the period of captivity. Containers were resupplied with small amounts of moist leaf litter once each week, and misted with distilled water using a pump-spray bottle every one to two days. Faecal material was allowed to accumulate in containers while millipedes were in captivity. The leaf litter should never become dry, but also should never be water-saturated. Animals were successfully kept under the conditions outlined above for several months at a constant $18^{\circ} \mathrm{C}$ on a $7: 17$ hours light:dark cycle.

\section{NOTES ON NATURAL HISTORY}

Much of the fauna native to south-western Western Australia is adapted to the prevailing Mediterranean climate, with its hot, dry summers, and cool, wet winters (Hopper and Gioia 2004). Many native animals, including millipedes, breed exclusively during the wet winter months of May-September (Harvey 2002). Antichiropus millipedes will start to emerge as soon as winter rainfall commences (and potentially slightly earlier for some species). Peak emergence of adult $A$. variabilis was in May of 2007, and June of 2009; these dates corresponded with the onset of winter rainfall (see Figure 5). Antichiropus variabilis adults can generally be found from emergence up until approximately October (Figure 6). Additional Antichiropus juveniles and penultimate individuals can sometimes be found during the warmer summer months, in moist litter and humus, but are virtually impossible to identify to species as they lack the adult male genitalia used almost exclusively in millipede taxonomy. During the summer months individuals burrow down deep into the soil to avoid desiccation (Harvey 2002). It also appears that A. variabilis may live for at least two years. This is based on the observation that over subsequent winter field seasons two distinct age cohorts were seen: one set of approximately half grown juveniles (presumably hatched the year prior) and another set of adult animals (presumably hatched two years prior) (J. Wojcieszek, pers. obs.).

Females lay eggs towards the end of winter (JulyAugust), and laying dates (as inferred by offspring emergence times) do not seem to be dictated by the time of adult emergence (which was, as discussed, partly dependent on winter rainfall) (see Figure 7). Females laid eggs deep within the soil of their containers, thus egg-laying was never observed. Antichiropus variabilis 


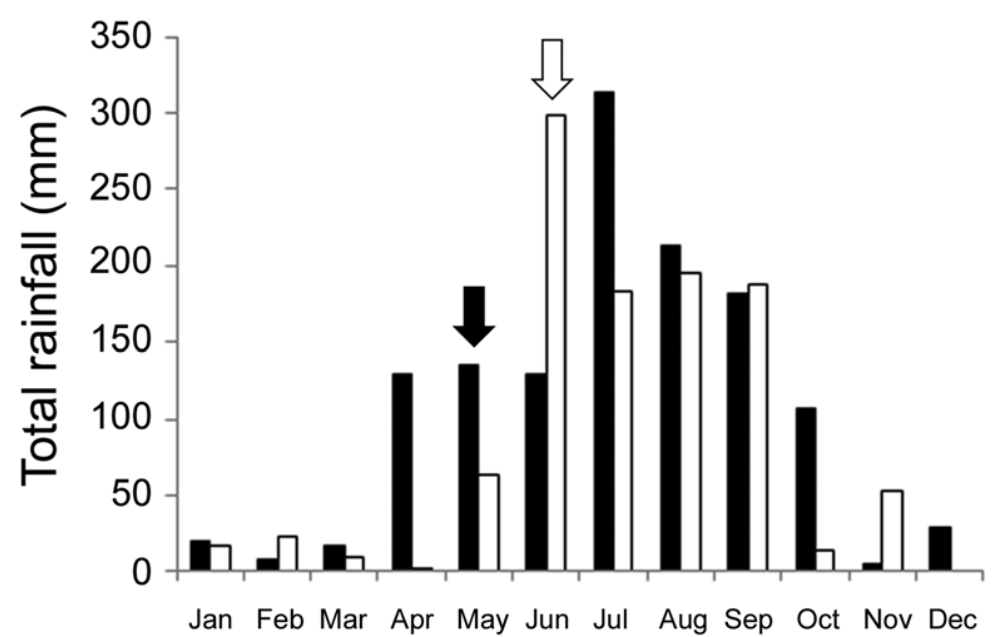

FIGURE 5 Total rainfall at Karnet, Western Australia, near the Serpentine Falls National Park collecting site, for 2007 (solid bars) and 2009 (open bars) (courtesy of the Australian Bureau of Meteorology). Arrows show times of mass emergence of millipedes in each of the two years, which only occurred following the onset of winter rainfall.

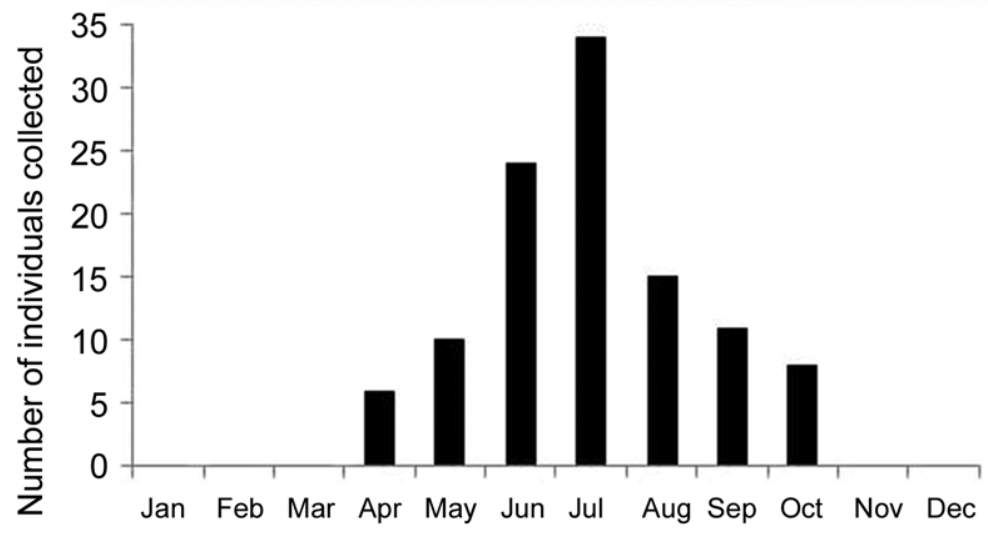

FIGURE 6 Bar graph showing absolute numbers of adult Antichiropus variabilis millipedes collected and deposited in the Western Australian Museum as of February 2010. Peak abundances reflect the period of winter rainfall in Western Australia (see Figure 5), and mass emergence of adults may therefore vary based on the timing of the initial winter rainfall.

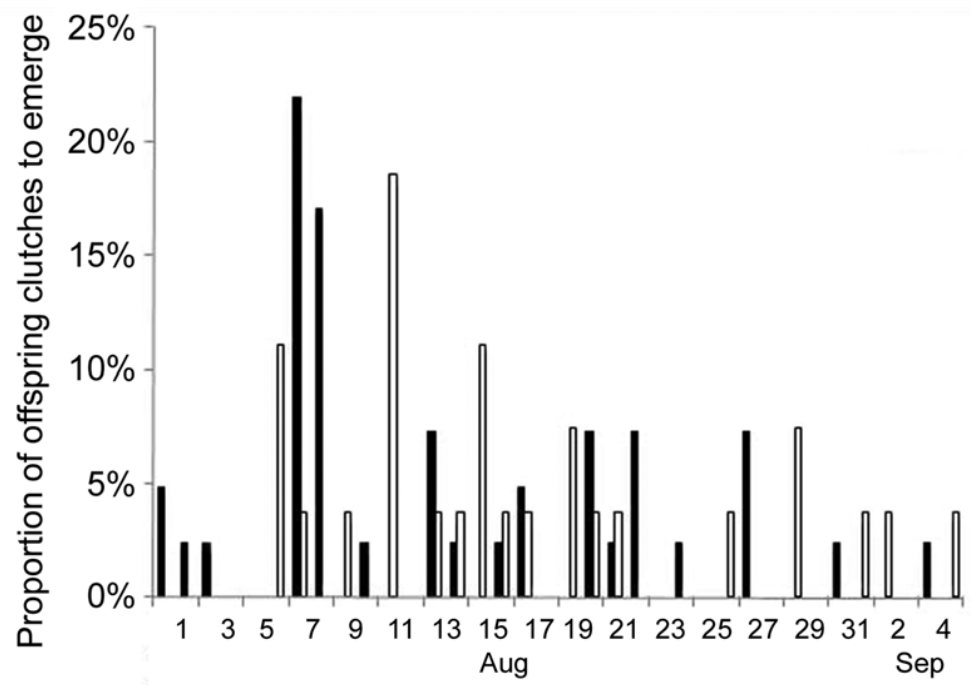

FIGURE 7 Distribution of offspring emergence times following the 2007 (solid bars) and 2009 (open bars) breeding experiments. Here we recorded the date at which offspring emerged from nests, at Stadium II. Exact egglaying and egg-hatching dates are not known. 

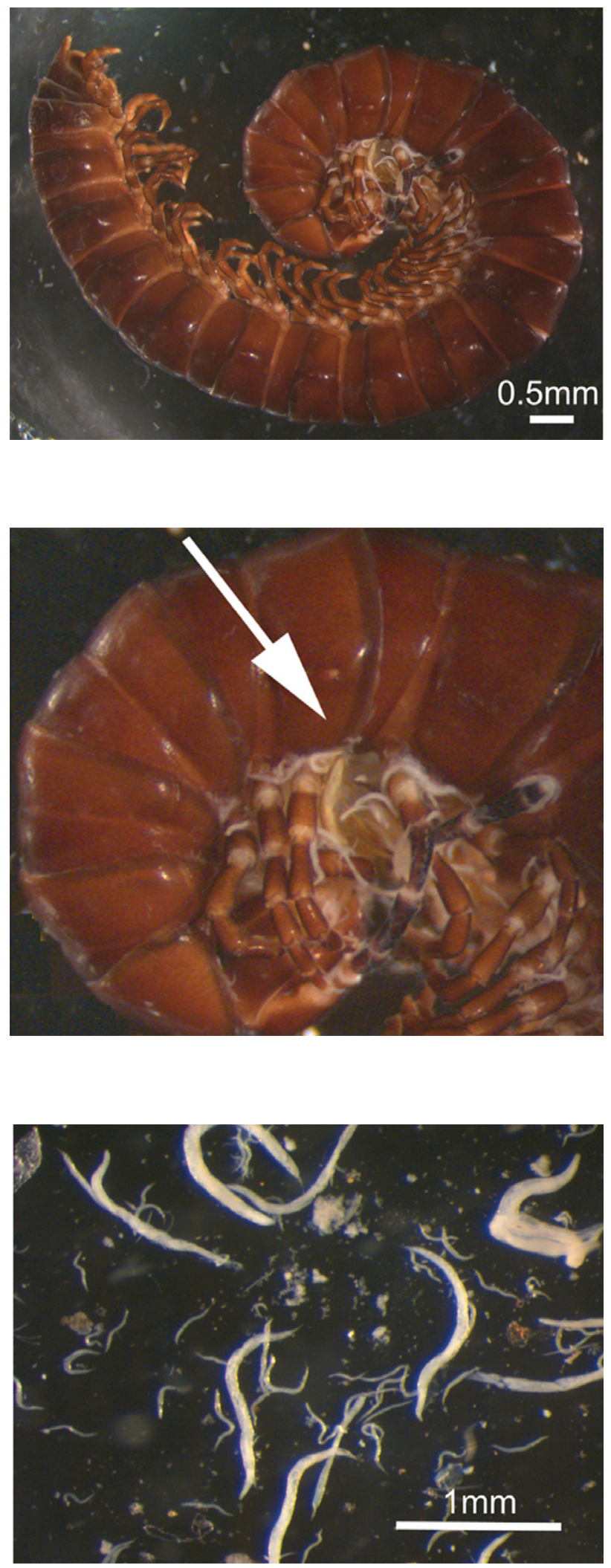

FIGURE 8 Deceased male Antichiropus variabilis with a nematode infection. Arrow shown on centre image is a magnified section highlighting exit points for nematodes. In the lower image, a mass of the infecting nematode parasites is shown (Order: Oxyurida). Images by J. Wojcieszek. is semelparous - once individuals moult to sexual maturity, they mate and breed for one winter season and then die. Antichiropus variabilis females usually died one to two days after egg-laying. However, when housing conditions were optimal in 2009, 38\% of females laid a second, smaller clutch of eggs, on average 31.8 days $( \pm S D 12.5$; range $13-49)$ after the first clutch was laid. It was not clear exactly how long it took for eggs to hatch after being laid. Under our standardised laboratory conditions, however, offspring were seen to emerge from nest capsules an average of 19 days after eggs had been laid (median $=18$ days, mode $=16$ days). The emergent offspring were in Stadium II (i.e. with six pairs of legs; see Hopkin and Read 1992: 119) on emergence from nests. Following emergence, offspring were frequently seen to form moulting chambers at the bases of containers, going through multiple moults in a matter of weeks. During our study, most offspring were preserved on emergence for molecular analyses. However, offspring from four different mothers were kept and monitored post-hatching under our standard conditions (constant $18^{\circ} \mathrm{C}$ with a $7: 17$ hours light:dark cycle). Approximately 20 weeks post-emergence most of these offspring had reached stadium IV, with a total of 17 pairs of legs (see Figure 4).

\section{COMMON PROBLEMS ENCOUNTERED}

In 2007, before optimal moisture, soil and leaf litter levels had been determined, large numbers of fatalities were observed among adult A. variabilis. Some of the deceased individuals were infected with a nematode parasite (see Figure 8), which may or may not have been the direct cause of death. The infecting nematodes were identified as belonging to the Order Oxyurida, which are intestinal parasites of invertebrates and vertebrates (Poinar 1983). Oxyurids have been identified as parasites of other millipede species (Wright 1979; Poinar 1983; Bowie 1985). Three infected millipede individuals have been deposited at the Western Australian Museum (WAM T102750-52), in addition to nematode specimens (WAM V7614). It is important to note that once housing conditions had been optimised in 2009, there was only one case of nematode infection observed. It is therefore possible that nematodes infect many individuals in a population, but that the infection escalates and becomes fatal if individuals are highly stressed and not held in suitable conditions. It was also common to see some fungal growth inside the individual containers, and it is possible that this may have adversely affected some individuals. Keeping containers low in fungus is therefore recommended. At one point, some soil was microwaved for approximately 5 minutes, to see if this reduced the amount of fungal infestation; surprisingly, this led to a large increase in fungal infestation, so this is not recommended. It would be best to take due care not to collect fungus when initially obtaining soil. Keeping animals in individual containers should also reduce the effects of both nematode infections and fungal infestation. 


\section{TISSUE PREPARATION FOR MOLECULAR ANALYSES}

Animals were successfully preserved for molecular analyses in $100 \%$ ethanol or by freezing at $-20^{\circ} \mathrm{C}$ or $-80^{\circ} \mathrm{C}$. The defence chemicals (hydrogen cyanide, and its precursor, mandelonitrile) seemed to interfere with DNA analyses, potentially due to inhibition of the Taq polymerase enzyme used in polymerase chain reactions (PCRs) (Wojcieszek and Simmons 2009). For this reason, tissue for DNA extraction should be taken from the head, or potentially from the legs and antennae (all devoid of chemical glands). If the exoskeleton has been cut at points along the animal, however, the defence chemicals may penetrate some of these tissues, making extraction of high-quality genomic DNA difficult. A variety of DNA extraction kits have proven successful in the laboratory (e.g. HiSpEx, Qiagen) using multiple macerated legs of individuals. Eleven polymorphic DNA microsatellites have also been isolated from $A$. variabilis, and many of these loci were successfully amplified from several other Antichiropus species (Wojcieszek and Simmons 2009).

\section{ACKNOWLEDGEMENTS}

We thank Leigh Simmons and Maxine Beveridge (University of Western Australia) for their assistance in the laboratory, Karen Edward for help during field collecting, Hugh Jones for identifying the nematode parasites and Mark Wojcieszek for providing photographs. Bob Mesibov and Petra Sierwald provided helpful comments that greatly improved this manuscript. We also thank the Australian Bureau of Meteorology for the provision of rainfall data. Scanning electron microscopy was carried out at the University of Western Australia's Centre for Microscopy, Characterisation and Analysis (CMCA) - a facility funded by the University, State and Commonwealth Governments. This research was enabled by funding from the School of Animal Biology at the University of Western Australia (UWA), in addition to a Holsworth Wildlife Research Endowment, and a Grant in Aid of Research Training from the UWA Graduate Research School, both awarded to J. Wojcieszek.

\section{REFERENCES}

Attems, C. (1911). Myriopoda exkl. Scolopendridae (pp. 147-204). In: Michaelsen, W. and Hartmeyer, R. (eds), Die Fauna Südwest-Australiens, vol. 3. Gustav Fischer: Jena, Germany.

Barnett, M., Telford, S.R. and De Villiers, C.J. (1993). Sperm displacement in a millipede? An investigation into the genital morphology of the southern African spirostreptid millipede Orthoporus pyrhocephalus. Journal of Zoology 231: 511-522.

Barnett, M., Telford, S.R. and Tibbles, B.J. (1995). Female mediation of sperm competition in the millipede Alloporus uncinatus (Diplopoda: Spirostreptidae). Behavioral Ecology and Sociobiology 36: 413-419.

Bowie, J.Y. (1985). New species of rhigonematid and thelastomatid nematodes from indigenous New Zealand millipedes. New Zealand Journal of Zoology 12: 485-503.

Environmental Protection Agency (2009). Sampling of short range endemic invertebrate fauna for environmental impact assessment in Western Australia. In: Guidance for the Assessment of Environmental Factors (in accordance with the Environmental Protection Act 1986).

Harvey, M.S. (2002). Short-range endemism among the Australian fauna: some examples from non-marine environments. Invertebrate Systematics 16: 555-570.

Harvey, M.S. and Mesibov, R. (2007). The millipede order Polydesmida in Australia: data, distributions and gaps. In: Unpublished Report to the Department of Environment and Heritage.

Hopkin, S.P. and Read, H.J. (1992). The biology of millipedes. Oxford University Press: New York.

Hopper, S.D. and Gioia, P. (2004). The Southwest Australian Floristic Region: evolution and conservation of a global hot spot of biodiversity. Annual Review of Ecology Evolution and Systematics 35: 623-650.

Jeekel, C.A.W. (1982). Millipedes from Australia, 1: Antichiropodini from South Australia (Diplopoda, Polydesmida, Paradoxosomatidae). Bulletin Zoölogisch Museum, Universiteit van Amsterdam 8: 121-132.

Moir, M.L., Brennan, K.E.C. and Harvey, M.S. (2009). Diversity, endemism and species turnover of millipedes within the south-western Australian global biodiversity hotspot. Journal of Biogeography 36: 1958-1971.

Poinar, G.O. (1983). The natural history of nematodes. PrenticeHall Inc.: New Jersey, U.S.A.

Shear, W.A. (1992). A new genus and two new species of millipedes from the Cape Range, Western Australia (Diplopoda, Polydesmida, Paradoxosomatidae). Records of the Western Australian Museum 15: 777-784.

Walls, J.G. (1999). The guide to owning millipedes and centipedes. T. F. H. Publications: Neptune City, U.S.A.

Wojcieszek, J.M. and Simmons, L.W. (2009). Isolation and characterisation of 11 polymorphic microsatellite loci in the millipede Antichiropus variabilis Attems (Diplopoda: Polydesmida: Paradoxosomatidae). Molecular Ecology Resources 9: 1208-1211.

Wright, K.A. (1979). Trichomycetes and oxyuroid nematodes in the millipede Narceus allularis. Proceedings of the Helminthological Society of Washington 46: 213-223.

MANUSCRIPT RECEIVED 9 FEBRUARY 2010; ACCEPTED 10 JUNE 2010 